\title{
Recognition and liquid authority
}

\author{
OLE JACOB SENDING \\ Director of Research, Norwegian Institute of International Affairs (NUPI), Oslo
}

E-mail: ojs@nupi.no

To analyze how authority emerges, become institutionalized, and may be transformed, we are best served with a concept of authority that highlights its dynamic features, and that captures the multiplicity of actors involved in producing and sustaining it. Extant accounts tend to operate with a view of 'solid' authority, but such a concept of authority is mainly descriptive, not explanatory. A turn to the liquid features of authority is not only better suited to account for global authority, but also for those pockets of 'solid' authority that we can find in the global or international sphere. I develop an account of authority that draws selectively from some of Bourdieu's core concepts and highlight the inherently relational aspect of authority. Authority, I submit, is based on actors' search for recognition. Such a perspective is better able to account for how authority emerges and may stabilize as 'solid,' and also be transformed over time. I draw on examples from the World Health Organization and the UN Security Council to illustrate the argument.

Key words: Authority; recognition; UN Security Council; World Health Organization

Nico Krisch asks us to consider that authority in global governance should be analyzed not as 'solid' but as 'liquid.' Importantly, he treats dynamism as a defining feature of liquid authority, with informality and multiplicity as potential drivers of such dynamism. I build on this conceptualization and extend it by arguing that the conventional view of authority as 'solid' is of limited analytical value. This argument rests on a distinction between authority as a descriptive and as an explanatory concept. Scholars that work with a 'solid' concept of authority - as commands and obligations are correct in describing or defining a variety of actors and institutions as having solid authority in the sense of issuing commands and creating formal obligations (see Cooper et al. 2008). The UN Security Council (UNSC) and the International Criminal Court, for example, may be said to have elements of such solid authority. But this is different from using that same concept in an analytical sense to account for the emergence and possible transformation of such authority. If we want to account for the 'degree to which authority is actually present in international politics' and 'the ways in which authority is created and maintained' (Krisch 2017), we are better 
served by analytical tools that can explain its dynamism. Thinking in terms of liquidity, I contend, allow us to better explain how the different forms of authority (characterized by both command and deference) that are on display in global governance emerge and may be transformed.

I identify a problematic aspect of most extant accounts of authority that hail from the tendency to treat it as an attribute of particular actors rather than as something that inheres in relations between actors. Drawing on Bourdieu's sociology, I treat authority as relational, and seek to specify the dynamism of authority as a product of actors' search - and struggle - for recognition within always already hierarchically organized social spaces. On this view, authority can take different forms, is not linked to predefined sources (rational-legal, expertise, moral, etc.) or types of actors (bureaucracies, expert groups, advocacy groups), and is something at stake in how actors engage one another (Sending, 2015). I illustrate the argument with examples of the transformation of authority (World Health Organization) and the liquid foundation of "solid" authority (UN Security Council).

\section{Actor attributes and the solidity of authority}

The literature on global governance has produced important insights about the different types of actors that may have authority in global governance, be they international organizations, non-governmental organizations, expert groups, or advocacy groups. These actors, we have learned, can have expert authority (Haas 1992), moral authority (Price 2003), bureaucratic authority (Barnett and Finnemore 2004), delegated authority (Koremenos and Snidal 2001), or any combination of these. The analytical categories used in these analyses do not, however, easily lend themselves to explanations of why some actors rather than others emerged in a position of authority, or how such authority may be transformed over time. The reason is that authority is made an attribute of the actors under analysis, and these attributes are said to emerge from these actors' access to ideal typical 'sources' of authority. This cuts us off from analyzing empirically what the actors in question see as being a mark or source of authority, and how such sources may change over time.

For example, Barnett and Finnemore's (2004) account of the authority of IOs invoke ideal-typical sources of authority - legal-rational, expertise, and moral authority - and move on to highlight attributes of IOs that fits with these sources of authority: IOs are rule-following (legal-rational authority), they embed expertise (expert authority), and they advance shared social and political objectives (moral authority) (2004, Ch.1). This is a highly potent 
classification of types of authority which has demonstrated that IOs' authority may be independent of their delegation from states. But a classification is no theory. How, for example, did the UN Department of Peacekeeping Operations emerge with authority to manage UN peacekeeping efforts, while its sister-organization - the UN Department for Economic and Social Affairs - is (almost) nowhere to be seen in the global governance of economic matters? The same set-up characterizes the literature on advocacy groups. Thomas Risse notes that 'Moral authority is directly related to the claim by transnational civil society that it somehow represents the "public interest" or the "common good" rather than private interests' (Risse 1999, 186). Here, too, it becomes difficult to explain why some groups rather than others are able to appropriate a position from which to make such claims. Avant et al. make a similar point in their discussion of 'principled authority,' and stress that the scope of such authority is limited to those that already share the moral or principled values in question $(2010,13)$. This leaves us in the dark as to how authority is at work, or not, in how advocacy groups are able to advance their goals vis-à-vis actors that do not share the same values.

These authors advance what Krisch refers to as a 'deference' model - one that is closely associated with the concept of 'liquid' authority advanced here. They nonetheless approach authority as something that is linked to actors' attributes. These attributes are defined by the analyst, so the task is to identify whether the actor in question (an expert group, an IO, an advocacy group) have attributes that matches ideal-typical sources of authority. But inasmuch as authority describes a relationship between actors, it is problematic that such an account all but omits from view the 'social dynamism' (Krisch 2017) that underwrites authority. It does so because it has few analytical tools with which to capture how other actors - those that presumably see these actors as authoritative - recognize (or not) these attributes as according them authority. If we want to empirically capture how authority emerges and how it may stabilize and take on a 'solid' form and be transformed over time, we need analytical concepts that focus on the relations between actors rather than working with pre-defined categories of particular actors. There is a more fundamental point here, namely the tendency to ignore that what we typically designate as actors - such as states, IOs, expert groups, or advocacy groups - are observers abstractions from continuously negotiated interactions among persons and sets of persons' (McAdam et al. 2001, 12). The implication is that we should try to unearth the social dynamics that are at work in either reproducing or transforming such actors, and the relations they may have with others.

There are elements of a relational perspective in more recent work on authority in global governance in the sense that they all refer to authority as 
being defined by it being recognized by the actors in question. Lake $(2009,8)$ presents his social contract-based conception of authority by noting that it 'does not exist without recognition.' Zürn et al. similarly motivate their analytical distinction between authority and legitimacy by noting that the two 'implies two layers of recognition' (2012, 83). And Avant et al. asserts that 'Authority is created by the recognition, even if only tacit or informal, of others' $(2010,10)$. Below, I develop an account of authority that foregrounds recognition as an essential aspect. My argument dovetails with that of Michael Zürn in this symposium, but where Zürn focuses on the identity and operations of actors with 'reflexive authority', I take a more structural perspective and focus on the relations between actors, and on the structured social spaces within which these operate. I contend that by focusing on the dynamics of recognition we can get a better grasp of the dynamism of authority, the multiplicity of actors with stakes in according or withholding recognition of authority, and the ideational resources that actors bring to bear in these processes. It allows us to explore at least two key aspects of 'liquid' authority as set out by Krisch's framing to this symposium. First, it allows us to treat the strength or degree of institutionalization of authority - in a descriptive sense - not as a matter of its ideal typical source or as an attribute of a specific actor or institution, but as a continuum between solidity and liquidity (Krisch 2017). Second, it gives us specific analytical leverage as an explanatory concept to 'study the social processes' of how authority - both liquid and solid - is created and evolve over time (Krisch 2017).

\section{Authority and recognition}

As a starting point, we can define authority as a relationship between a superordinate and a subordinate actor, which is recognized, and where the latter defers to the former (Friedman 1990, 60-62). Friedman notes that

To bring out the precise character and role played by the element of 'recognition' or 'belief' that a person is entitled to rule (or to speak) within the authority relation, it is necessary to observe that the relationship must possess another feature in addition to the element of deference .... And this is that there must be some public way of identifying the person whose utterances are to be taken as authoritative .... [S] ome public way of identifying authority is a logical requirement of deferential obedience wherever it is to be found in society (Friedman 1990, 68).

The upshot of this is that absent a clear sense of the importance of recognition in establishing relations of super- and subordination, it is difficult to account for the distinctiveness of authority, since an exclusive 
focus on the 'source' of authority - which explains deference - fails to capture that authority concerns relations between actors. This is why Friedman refers to the public identification (recognition) as a logical requirement of deferential obedience. Authority, on this reading, designates a relationship where there is a 'distinction between statement and speaker such that the latter can endow the former with its appeal.' (Friedman 1990, 69; emphasis added). Friedman notes in a similar vein that 'The concept of authority can thus have an application only within the context of certain socially accepted criteria which serve to identify the person(s) whose utterances are to count as authoritative. ...' (Friedman 1990, 71). We need only make a short yet consequential step from acknowledging that recognition is central to authority, to theorizing what recognition is and what it does to our understanding of authority. To see what is at stake, it is useful to briefly discuss one of the more advanced discussions of authority as an analytical concept for understanding world politics - that of David Lake's (2009) social contract perspective.

\section{Recognition and deference}

Lake rightly criticizes the 'formal-legal' conception of authority that prevails in the study of world politics for not being able to 'explain its own creation.' $(2009,28)$. For Lake, the key point is that authority, properly conceived, cuts across the distinction between domestic and international politics, because it turns not on 'the nature of authority or the origins of legitimacy, but on the extent of hierarchy and, in turn, the depth of vested interests that supports that hierarchy' (Lake 2009, 41; emphasis added). In so doing, Lake treats authority as a relational phenomenon that may take many - and more or less solid - forms. A key strength of Lake's social contract view of authority is that it captures the negotiated and contested character of authority - what we here discuss as its liquidity. He notes, for example, that '.. authority is always a product of and site of political struggle' and that 'What it means to be authoritative and what rights both the ruler and the ruled may legitimately possess is continually negotiated and renegotiated' (Lake 2009, 20).

But the social contract view nonetheless fails to capture the founding of authority: this is so because for Lake, authority is at heart about a contract between $\mathrm{A}$ and $\mathrm{B}$ in which the latter defers to the former in exchange for the latter's provision of some good (Lake 2009, 28-31). To the extent that 'authority is a dynamic and constantly evolving relationship ...' this relationship is - for Lake - one that is negotiated and that turns on the 'price' of the good that A offers relative to the price of B's deference 
or obedience, in which there is an 'equilibrium' (Lake 2009, 30). Lake contends that the good provided by the superordinate actor is a 'political order,' which is the 'glue that binds ruler and ruled in an authority relationship.' Indeed, this political order is of the essence because 'without the desired political order, the ruled have no reason to subordinate themselves to the commands of the ruler' (Lake 2009, 30; emphasis added).

This is where the contractual logic at the heart of Lake's conception of authority runs into trouble, for the relationship is presented as if subordinate actors continually assess whether or not they get what they want out of being in a subordinate position. If subordinate actors have 'no reason to subordinate themselves' - if they don't like the political order provided by the superordinate actor - it is assumed that the subordinate actor's assessment of self, of what is possible, smart, achievable, etc. is not affected by the authority relationship. What matters, rather, is what the subordinate actor, presumably based on cost-benefit analyses, invests in the contract, which makes it more robust: 'As actors invest in relationally specific assets, they become dependent on the authority structure that produces a particular order and in turn acquire incentives to support the ruler ...' (Lake 2009). This description - true to a contractual view - does not capture the distinctiveness of authority as a relationship in which there is a recognized hierarchy where the subordinate actor defers. In short, Lake equates deference with a choice to forego autonomy as long as there are good reasons to do so. In so doing, he conflates authority with hierarchy, and leaves us in the dark as to the distinct role of deference compared to choice and coercion.

While Lake is able to capture the contested and dynamic character of authority - and hence its liquidity - the prize paid is a reduction of the analytical purchase of authority as a particular type of relationship between actors. I advance a different conceptualization that aims to capture the liquidity and dynamism of authority, but in a way that retains a clear focus on how the authority relationship is constitutive of the identity of both actors, so that what is seen as a 'desired political order' becomes endogenous to the authority relationship. This means that the superordinate actor is able to impose the very categories through which subordinate actors define and orient themselves vis-à-vis relevant others. Specifically, I contend that the very engine behind the construction and maintenance of authority is actors' constant search for recognition within institutional contexts that are always already (although to various degrees) hierarchically structured. While any institutionalized social (and political) setting has elements of hierarchy, what distinguishes authority relationships is the ability of some actors to naturalize or universalize their particular interests and to impose the categories and evaluative criteria by which 
others are compelled to refer to as they seek recognition. Deference, therefore, is produced by subordinate actors search for recognition within parameters not of their choosing.

\section{Recognition and misrecognition}

Bourdieu's sociology is aimed at capturing social life as inherently relational. The concept of field, for example, zooms in on 'relations between positions anchored in certain forms of power (or capital) ...' (Bourdieu and Wacquant 1992, 16). Not all social spaces have field properties, but those that are, are marked by a 'centripetal force' which attracts agents towards each other, and this centripetal force 'is provided for by the specific stakes for which different agents act/play in order to win or resist' (Bigo 2007, 239). The different actors' interests and strategies are shaped by their position relative to others in a field, which is defined by their volume and types of capital: actors seek to 'safeguard or improve their position and to impose the principle of hierarchization that is most favorable' to the capital that they possess (Bourdieu and Wacquant 1992, 101). Many authors have applied Bourdieu's conceptual tools to great effect, also in the study of world politics (Williams 2006; Pouliot 2010; Bigo 2011; Adler-Nissen 2012). What has not been addressed explicitly is that the purchase of the concept of field, and of capital, depends crucially on one additional element: that the competition within fields stem from actors' search for recognition. Not only does it underwrite Bourdieu's concept of symbolic capital. It is arguably necessary also for the concept of fields as a 'game' that is worth investing in (Schiff 2014). Steinmetz argues, for example, that Bourdieu has to presume a universalized drive for recognition in order to make his concepts of field and capital work effectively:

The dominated may develop a 'taste for necessity,' preferring their own (dominated) tastes to those of the elite. But they recognize the dominant as holding more valuable cultural capital, that is, dominated and dominant recognize the same principle of domination. The dominant are granted recognition not just by their elite peers but also by the dominated participants in the field (Steinmetz 2006:454-55).

It is the drive for recognition that underwrites Bourdieu's assertion that any actor is 'continuously led to take the point of view of others on himself, to adopt their point of view so as to discover and evaluate in advance how he will be seen and defined by them' (Bourdieu 2000, 166). It is, moreover, the drive for recognition that accounts for what Steinmetz' (2006) calls the 'doubling' of capital in Bourdieu's work: cultural capital, say, can be transformed into symbolic capital when and if it is recognized by others as being 
the metric by which all other resources, or forms of capital, are assessed and attain their value (see also Steinmetz 2008). On this view, authority emerges as a result of actors' search for recognition, where some actors have 'obtained sufficient recognition to be in a position to impose recognition' (Bourdieu 1989, 23) by virtue of shielding or transforming their particular resources into 'rules' that all actors have to refer to in order to gain recognition. It is in this sense that symbolic capital implies recognition on the part of dominant actors, and (mis-) recognition on the part of dominated ones, as the latter help reproduce the evaluative criteria that defines their subordinate position by virtue of seeking recognition on terms set by others.

Seen in this way, relations of authority are established and perpetuated in a way that typologies of types of authority cannot capture: subordinate actors defer to the dominant actors not because of coercion or because of the incentives offered, as in Lake's view. Nor do actors defer because they have internalized particular belief systems and made these part of their identity, as can be inferred from Weber's ideal types. Rather, all actors deploy the resources at their disposal in an effort to be recognized by the evaluative criterion that prevails in any given field, and this evaluative criterion is some actors' (particular) capital misrecognized as the rules or standards against which all actors are evaluated.

What is the mechanism by which some actors are able to produce the categories through which others see and understand the world? For Bourdieu, this operates through the 'production of belief,' which concerns the ability of some actors to present and win acceptance for their categories (or social criteria) - necessarily structured by their particular interests as natural and/or universal ones. In Loic Wacquant's summary

Bourdieu's entire oeuvre may be properly read as a quest to explicate the specificity and potency of symbolic power, that is, the capacity that systems of meaning and signification have of shielding, and thereby strengthening, relations of oppression and exploitation by hiding them under the cloak of nature, benevolence, or meritocracy (Wacquant 2005, 134, emphasis added).

This is important, for it means that whatever ideal-typical 'sources' of authority that we may identify as important in constituting authority are historical products where some actors have been able to transform resources into rules, or particular interests into universal ones. It also means that rather than link some actor's authority to a particular source of authority, we should seek to capture the production and effects of such beliefs as manifested in the categories and evaluative criteria that may prevail in any given social space. Doing so allow us to account for the initial founding of authority, and for how authority may evolve over time. 
In summary: all actors strive for recognition, and do so within social spaces that are marked by more or less articulated hierarchies in terms of what resources, or beliefs, are valued by others. These structural features are important, since they define the conditions of possibility for how some actors may appropriate resources that enable them to impose the categories and evaluative criteria that others are compelled to refer to in their quest to gain recognition. To the extent that these categories are taken for granted or are not explicitly challenged, the socially produced and contingent character of social life is suppressed, and subordinate actors help perpetuate the conditions of their position as subordinate. By zooming in on recognition as central to authority, and exploring its social dynamics, we can see how authority is something that is at stake in how actors engage one another and deference a product of such social dynamics.

\section{Liquid authority in global governance: the case of the World Health Organization (WHO)}

Emphasizing the liquidity of authority allows us to capture how authority is something that is subject to challenge and transformation. Consider the WHO: it has a separate parliamentary body (the World Health Assembly), a fairly unitary knowledge base of medical and public health experts, and builds on a long tradition, from the late 19th century onwards, of international health cooperation. Its constitution explicitly states that the WHO is to 'act as the directing and co-ordinating authority on international health work' (Hanrieder 2015, 191). It was the authority par excellence on global health from its establishment in 1948 until the 1980s. From the 1980 onwards, however, the WHO's position as the international authority on health was challenged (Hanrieder 2015). Explaining this transformation requires that we attend to how a multiplicity of actors competed for a position of authority from which to shape international health governance.

A key event in the transformation of the WHO was the formulation of the 'Declaration of Primary Healthcare' from Alma-Ata in 1978. It was viewed with skepticism by the US and a range of US-dominated IOs because it emphasized a so-called 'intersectional' approach to health that brought socio-economic development to the core of health considerations. Already the following year, a conference was held at the Rockefeller Foundation's Bellagio center in Italy with the aim of forging an alternative. It was sponsored by the Rockefeller Foundation and co-organized with the World Bank, and featured the head of USAID and UNICEF as well as the President of the World Bank and the Vice President of the Ford Foundation (Brown et al. 2006, 67). The participants forged an alternative to the Alma-Ata 
declaration that focused on cost-effective and targeted interventions to improve health. UNICEF soon thereafter launched a series of projects aimed at operationalizing this alternative to the Alma-Ata declaration. (Brown et al. 2006). Also in 1979, the World Bank started to give loans earmarked for health investments and established a separate Population, Health, and Nutrition Department. It also began to link health to economic growth, and to call for more efficient use of resources as well as calling for greater private sector involvement in health governance (Ruger 2005). Both UNICEF and the World Bank thereby entered the field of health by advancing different sets of policies, and privileging economic considerations as central to health policy. In so doing, they undermined the strength of the public healthgrounded evaluative criterion that had secured the WHO's authority since its establishment. This put the WHO in a precarious position, since both states and other IOs no longer recognized the WHO as the sole, and overarching authority on health issues. Instead, there were a multiplicity of actors, each with distinct claim to authority on some aspect of health issues.

This relative loss of authority for the WHO had an impact on its funding situation: From the mid-1980s onwards, member states first established a budget freeze, then started to shift from regular budget allocations (based on gross national product and population size) to extra-budgetary funding. By the early 1990s, extra-budgetary funding had overtaken regular budget support, one important implication being that the World Health Assembly had no say over extra-budgetary funds. As one author noted, by the early 1990s, the WHO was 'caught in a cycle of decline, with donors expressing their lack of faith in its central management by placing funds outside the management's control.' (Godlee 1995, 182). When the WHO sought to regain its position in the late 1990s, it was compelled to seek recognition on terms that had become institutionalized during the course of the last two decades through activities of the World Bank, UNICEF, and others. In the late 1990s, the WHO established a Commission on Macroeconomics and Health, chaired by Jeffrey Sachs, which emphasized that investments in health was vital for economic growth. It also sought out partnerships with private firms and philanthropic organizations - such as the Gates Foundation - in forging public-private partnerships, and to make inroads beyond ministries of health in member states (Brown et al. 2006, 70). Through this process, the WHO was able to re-position itself, but now as a convener or focal point rather than as the single global authority on health. The dynamism of the authority structure in global health was thus a result of changing terms of recognition in the field of health, where actors originally outside the field of health governance marshaled new evaluative criteria - economic efficiency, targeted interventions, etc. - and undermined the authority of the WHO. We can hardly capture 
this dynamic, and the multiplicity of actors involved, if we focus on the formal-legal basis of WHO authority or the social contract that established the organization. The liquid form of authority here comes to light best through a focus on the practices of recognition and their changing terms.

\section{The liquid foundations of solid authority: the case of the UN Security Council}

Both global and domestic authority may be described as both 'solid' (singular and institutionalized), and as liquid (multiple and dynamic). But to account for both types of authority, we need an analytical concept of authority that foregrounds its dynamism and thus its liquidity. This is so because authority describes a relationship between actors, and lest we can assume that relations between actors remain fixed, the dynamism of relations between the (multiplicity of) actors would have to take center stage to account for it. This is particularly important for efforts to account for how authority may emerge and become institutionalized (and thus more or less solid) as well as how it may be transformed. Take state authority - arguably the most 'solid' form of modern political authority. To account for its establishment and evolution over time, we need detailed empirical analyses, starting with the process of state formation, which is difficult to grasp if we operate with a concept of already established, 'solid', authority (Elias 1939/2000; Bourdieu 2014). Similarly, the literature on contentious politics spearheaded by McAdam, Tarrow and Tilly (2001), show how state institutions with 'solid' authority may be challenged and transformed in fundamental ways by different modes of protest and mobilization, again suggesting the importance of bringing the dynamism between actors to center stage, also in accounting for solid authority.

Similar dynamics are visible in global governance. The UN Security Council (UNSC) is vested with the 'right of command' and states are obligated to comply with Council resolutions. It is the closest we get to 'solid' authority in world politics. As such, it is a hard case for demonstrating the analytical purchase of a liquid concept of authority. It is useful here to build on Lake's view of authority, since it foregrounds the dynamism involved in establishing authority. Lake's framework makes us focus on how - during the negotiations of the UN Charter - member states of the UN assessed the 'cost' of subordination to the UNSC and the veto powers in exchange for the benefits of a promised 'order' to be upheld by the Council. What is not captured in Lake's framework is that that the contents of the proposal on the composition and authority of the Security Council was the result of negotiations between the Big Four - pushed by the United States - rather than a negotiation between the Big Four and all other states (Schlesinger 2003, 40-45). A commentator in the New York Times noted during the San 
Francisco conference that 'The smaller nations have reluctantly accepted the idea of virtual world dictatorship by the great powers.' (quoted in Schlesinger 2003, 171). Rather than assessing the cost and benefits of a 'contract', other states were compelled to engage in negotiations on terms already defined by these four states (later to be joined by France). Other states accepted the proposal by the 'Big Four' as it reflected a new hierarchy, based first and foremost on military strength. In Mazover's summary, the UN 'represented a deliberate retreat from the League's comparative egalitarianism back to the great power conclaves of the past.' (Mazover 2009, 149). This hierarchy was presented in terms of great power responsibility, where the veto powers would shoulder the burden of preserving 'international peace and security,' thereby legitimating their special status. As such, the veto powers defined the credibility of the Council, and of the UN, to deliver 'international peace and security' in a way that required them being in control. Indeed, the Big Four, had decided in advance of the San Francisco conference that they had the right to veto all proposals to amend the draft Charter from other states, thereby setting strict terms for engagement. The dynamics by which the Council's ('solid') authority was established is thus to be found in the fact that some states defined the categories - through the Dumbarton Oaks Charter - through which others approached the negotiations in San Francisco. The existence of hierarchy between states was thus transformed into authority by virtue of setting terms on which less powerful states had to seek recognition for their particular concerns. Some 40 states had raised concerns with the veto arrangement during the negotiations, but at the end of the day, smaller states deferred not because of an assessment of cost, but because the terms for negotiations were such that the Big Four pinned the responsibility of possible failure on sub-ordinate states. One participant noted with reference to efforts by less powerful states to reduce the veto power that: 'However far apart we (the Five Powers and small and medium powers) still are, a conciliatory solution is not impossible, for everyone is beginning to realize that the veto is a necessity and that its limits could not be further defined without risks for which no one wishes seriously to assume responsibility' (Schlesinger 2003, 102; emphasis added). In other words, the very framing of the negotiations by the Big Four was based on a particular allocation of responsibility, where the Big Four legitimized their control of the organization based on military strength, and defined efforts to undermine that veto power as being irresponsible.

The extent to which the Security Council is suffused with a social dynamic of recognition can be further specified in terms of its contemporary functioning. Two key points stand out. First, the social processes through which authority is reproduced that operates underneath the formal-legal structure of the Council. Second, the extent to which the Council's authority has 
expanded over time to new areas, which depend on recognition in the wider political setting in which the Council operates. I discuss each point in turn.

The social processes within the Council are important for understanding the contents of resolutions. While there are five states with veto powers, there are historically established differences in how these states advance their interests, which shapes the contents of resolutions. United Kingdom, France, and the United States are referred to within the Council and by others as 'P3', and they hold an edge vis-à-vis China and Russia by dint of investing in drafting resolutions. They typically take on role as 'penholder' - responsible for drafting resolutions as a basis for negotiations. As a seasoned diplomat in New York observed, 'Western great powers P3 - still has the power to define as 'penholder' almost all resolutions. Russia's main interest is to shore up against the West, and they are rarely successful when they take the initiative, while China's behavior is more passive. ${ }^{1}$ The position of the P3 within the council to set the agenda and take lead on drafting resolutions in this way, for example through the role of penholder, depends on recognition of this practice, from both China and Russia, as well as elected members. That is, the process of drafting resolutions requires specific skills, the assessment of which is made against the standard established by the P3's mode of operations. This aspect of the functioning of the Council matters for the contents of resolutions. For example, Adler-Nissen and Pouliot has shown how the United Kingdom, based on its 'recognized [competence] in New York for its superior skills in the many legal technicalities that often bog down the Council,' were able to seize initiative in drafting resolution 1970 on Libya, with the effect that debates about the resolution amounted to 'fine tuning' the UK proposal $(2014,10)$.

The practices through which resolutions are produced also matter for the role of elected members in ways that we are unable to capture if we primarily at the institutional set-up of the Council and the 'constitutional' roles of the permanent members. Indeed, the role of elected members is central for embedding the privileges of the P5 within the nominal principle of sovereign equality. That is, the competition and resources invested diplomatically and economically - to get elected to the Council serve to reproduce the authority of the Council, and of the privileges of the P5 in that elected members seek recognition from permanent members for their role in supporting their respective agendas. Even though the permanent members cannot formally instruct elected members on their voting patterns,

\footnotetext{
${ }^{1}$ Interview, New York, February 10, 2013.
} 
there is a recognized relationship of super- and subordination where deference is produced by subordinated actors' search for recognition as team players, not disrupting established ways of doing things (Bosco 2009; Pouliot 2016). Schia (2013) notes with reference to the Norwegian tenure as elected member of the Council during the follow-up to the Iraq war that Norwegian diplomats sought first and foremost to be 'team players' and to not disrupt Council practice and relations with permanent members. The P5 had requested that only they, and not the elected members of the Council, get access to the weapons inspectors' report. This was justified by them having 'special requirements for additional access' compared with non-permanent members. Norway's delegation supported this decision (later to be criticized by the Foreign Minister for not consulting with him), because they wanted, in Schia's formulation, to be 'part of the parade.' (2013, 140).

While the Council's formal authority as per the Charter remains the same, it is difficult to account for the expansion of its authority from the late 1980s onwards without considering what Krisch calls the 'multiplicity of actors' involved, and also of the changes in the relations between key actors. The ability to pass resolutions mandating peace operations to engage in efforts to build liberal, democratic states - a considerable expansion of Council authority - was in part due to a transformation in the political make-up of one actor, the Soviet Union. This allowed the P3 and allies to work through another actor, the UN Secretariat, to advance liberal standards as a solution to post-conflict reconstruction as the framework within which to give mandates for UN peace operations (Paris 2003). The Council has also changed how it operates to extend the scope of its authority by inviting non-members to form part of 'group of friends' to address particular issues. As Jochen Prantl (2005) has argued, this amounts to an extension of scope, but also of a transformation of the role of the Council: 'groups of friends' are used for de facto crisis management, and the Security Council serves more as a legitimating body for activities performed by states under the guidance of the Secretary General. Prantl notes that 'diplomatic problem solving and its collective legitimation have become increasingly decoupled. The former tends to be delegated to informal groups or coalition of states, while the UN Security Council provides the latter.' $(2005,561)$. This transformation of the functioning of the Council depends on non-members' willingness to invest in crisis management with and for the Council in the name of 'systems maintenance' (Neumann 2015). In other words, non-permanent members seek, in joining informal groups of friends, recognition for their contribution to systems maintenance from peers and superordinate actors for their investment in, and distinct contribution to, international crisis management. 
While the authority of the UNSC can be seen as 'solid', then, we need analytical tools that hail from a more liquid conception to capture the founding of such authority, the changes in its scope, and the multiplicity of actors involved. Given that authority describes a relationship between actors, this should not surprise us. Authority may be institutionalized and be rightly described as solid, but this very solidity is based on stabilization of relationship between actors, which is subject to change. Changes in such relationship can occur in a variety of ways. A focus on dynamics of recognition allow us to capture both how authority is stabilized, expanded, and transformed as it treats authority as the outcome of processes where actors seek recognition from one another, and where the terms of such recognition-seeking is central to both the establishment and possible transformation of authority.

\section{Conclusion}

As conceived here, the concept of liquidity enables us to capture what sets global authority apart from domestic authority without engaging in a priori categorizations of actors, while still sharpening our focus on particular salient features of global authority, such as multiplicity and informality: Global authority is generally speaking less centralized and institutionalized, and lacks what legal scholars call 'competence-competence' - the ability of an institution to determine its own jurisdiction (see Isenbaert 2010, 45-46; Cohen 2012, 126). It is also lacks the degree of 'publicness' that characterize state institutions in many states in terms of a link between capacity and accountability, which flows from the degree and type of institutionalization of authority (Eriksen and Sending 2013).

Treating global governance as organized into more or less bounded social spaces that have a history and that are organized in more or less distinct hierarchies makes it possible to analyze empirically who is in a position to grant and to withhold recognition to others as having authority. Global governance, and the authority at stake in it, here emerges as being produced in and through social spaces - fields - organized around concepts of governance about which actors hold different conceptions. Actors in a field share a 'thin' interest in what is at stake in the field, specified as the observed investment of time and resources in what the field is about: how to define and govern specific objects (security, health, environment, human rights, etc.) (Sending 2015). The degree of institutionalization of what constitutes a mark of authority may vary (Steinmetz 2008): some issue-areas may be characterized by a high degree of institutionalization, and with more stable and 'solid' authority. A case in point is, perhaps, international trade law, 
with the WTO appellate body with capacity to make binding decisions in case of trade disputes.

Other issue-areas may be characterized by evaluating criteria being in flux or contested. Underneath the different forms that the authority in these different areas and institutions may take, however, are the continual search and struggle for authority that characterize relations between actors that engage in global governance. As such, a focus on liquid authority provides us with analytical tools with which to explore how authority may vary on a scale from solid to liquid, from firmly institutionalized to contested. Recognition is one operationalization of the concept of liquidity, as it zooms in on the inherently relational dynamic of authority, where actors deploy different resources to seek recognition, both vis-à-vis peers and superordinate actors.

\section{Acknowledgements}

I want to thank Nico Krisch and other symposium contributors as well as participants at a workshop on liquid authority at IBEI in Barcelona for comments on earlier drafts. Thanks are also due to the referees and the editors for helping to sharpen the argument. Funding has been provided by the Research Council of Norway through the project "Evaluating Power Political Repertoires”.

\section{References}

Adler-Nissen, Rebecca. ed. 2012. Bourdieu in International Relations. London: Routledge.

Adler-Nissen, Rebecca, and V. Pouliot. 2014. "Power in Practice: Negotiating the International Intervention in Syria." European Journal of International Relations 20(4):889-911.

Avant, Deborah, Martha Finnemore, and Susan Sell, ed. 2010. Who governs the globe? Cambridge: Cambridge University Press.

Barnett, Michael, and Martha Finnemore. 2004. Rules of the World: International Organizations in Global Politics. Ithaca, NY: Cornell University Press.

Bartelson, Jens. 2013. “Three Concepts of Recognition.” International Theory 5(1):107-29.

Bigo, Didier. 2007. The Field of the EU Internal Security Agencies. Collection Cultures et Conflits. Paris: L'Harmattan.

Bigo, Didier. 2011. "Pierre Bourdieu and International Relations: Power of Practices, Practices of Power." International Political Sociology 5(3):33.

Bosco, David L. 2009. Five to Rule Them All - The Security Council and the Making of the Modern World. Oxford: Oxford University Press.

Bourdieu, Pierre. 1989. "Social Space and Symbolic Power." Sociological Theory 7(1):14-25.

Bourdieu, Pierre. 2000. Pascalian Mediations. Cambridge: Polity Press.

Bourdieu, Pierre. 2014. On the state: Lectures at the Collège de France, 1989-1992. Cambridge: Polity, 2014.

Bourdieu, Pierre, and L. Wacquant. 1992. An Invitation to Reflexive Sociology. Chicago, IL: Chicago University Press. 
Brown, Theodore M., Marcos Cueto, and Elizabeth Fee. 2006. "The World Health Organization and the Transition From 'International' to 'Global' Public Health." American Journal of Public Health 96(1):62-72.

Cohen, J. 2012. Globalization and Sovereignty. Rethinking Legality, Legitimacy, and Constitutionalism. Cambridge: Cambridge University Press.

Cooper, S., D. Hawkins, W. Jacoby, and D. Nielson. 2008. "Yielding Sovereignty to International Institutions: Bringing System Structure Back In.” International Studies Review 10(3):501-24.

Elias, Norbert. 1939/2000. The Civilizing Process. Sociogenetic and Psychogenetic Investigations. Oxford: Blackwell.

Eriksen, S. S., and Ole J. Sending. 2013. "There is no Global Public: The Idea of the Public and the Legitimation of Governance." International Theory 5(2):213.

Friedman, R. B. 1990. On the Concept of Authority in Political Philosophy. Authority. J. Raz. New York: New York University Press, 56-91.

Godlee, Fiona. 1995. “WHO’s Special Programmes: Undermining From Above.” British Medical Journal 310:178-182.

Haas, Peter M. 1992. "Epistemic Communities and International Policy." International Organization 46(1):1-35.

Hanrieder, Tine. 2015. International Organizations in Time: Fragmentation and Reform. Oxford: Oxford University Press.

Hurd, Ian. 2005. "The Strategic Use of Liberal Internationalism: Libya and the UN Sanctions, 1992-2003." International Organization 59(3):495-526.

Isenbaert, Mathieu. 2010. "EC Law and the Sovereignty of the Member States in Direct Taxation". IBFD Doctoral Series 19. Amsterdam: IBFD.

Keck, Margareth, and Kathryn Sikkink. 1998. Activists Beyond Borders. Ithaca, NY: Cornell University Press.

Koremenos, Barbara, Charles Lipson, and Duncan Snidal. 2001. "The Rational Design of International Institutions.” International Organization 55(4):1-38.

Krisch, Nico. 2017. "Liquid Authority in Global Governance." International Theory 9(2):237-60. Lake, David. 2009. Hierarchy in International Relations. Ithaca, NY: Cornell University Press.

Mazover, Mark. 2009. No Enchanted Palace. Princeton: Princeton University Press.

McAdam, Doug, Sidney Tarrow, and Charles Tilly. 2001. Dynamics of Contention. Cambridge: Cambridge University Press.

Neumann, Iver B. 2015. "Institutionalizing Peace and Reconciliation Diplomacy: Third-Party Reconciliation as Systems Maintenance." in Diplomacy and the Making of World Politics, edited by Sending, Ole J, Pouliot Vincent, and Neumann I. B., 140-67. Cambridge: Cambridge University Press.

Pouliot, Vincent. 2010. International Security in Practice: The Politics of NATO-Russia Diplomacy. Cambridge: Cambridge University Press.

Pouliot, Vincent. 2016. International Pecking Orders: The Politics and Practice of Multilateral Diplomacy. Cambridge: Cambridge University Press.

Price, Richard M. 2003. "Transnational Civil Society and Advocacy in World Politics." World Politics 55(4):579-606.

Prantl, Jochen. 2005. "Informal Groups of States and the UN Security Council." International Organization 59(03):559-92.

Risse, Thomas. ed. 1999. The Power of Human Rights. International Norms and Domestic Change. Cambridge: Cambridge University Press.

Ruger, Jennifer Prah. 2005. "The changing role of the World Bank in global health." American Journal of Public Health 95(1):60-70.

Schia, Niels Nagelhus. 2013. "Being Part of the Parade: 'Going Native in the United Nations Security Council.'” Political and Legal Anthropology Review 36:138-56. 
Schiff, Jade. 2014. Burdens of Political Responsibility. Cambridge: Cambridge University Press. Schlesinger, Stephen. 2003. Act of Creation: The Founding of the United Nations. Boulder, CO: Westview Press.

Sending, Ole J. 2015. The Politics of Expertise: Competing for Authority in Global Governance. Ann Arbor, MI: University of Michigan Press.

Steinmetz, George. 2006. "Bourdieu's Disavowal of Lacan.” Constellations 13(4):445-64.

Steinmetz, George. 2008. "The Colonial State as a Social Field: Ethnographic Capital and Native Policy in the German Overseas Empire Before 1914.” American Review of Sociology 73(4):589-612.

Wacquant, Loic. 2005. Pierre Bourdieu and Democratic Politics: The Mystery of Ministry. Cambridge: Polity.

Williams, Michael C. 2006. Culture and Security: Symbolic Power and the Politics of International Security. New York: Routledge.

Zürn, Michael, Martin Binder, and Matthias Ecker-Ehrhardt. 2012. "International Authority and its Politicization." International Theory 4(1):69-106. 